\title{
SEROLOGICAL MARKERS AND RISK FACTORS RELATED TO HEPATITIS B VIRUS IN DENTISTS IN THE CENTRAL WEST REGION OF BRAZIL
}

\author{
Enilza Maria Mendonça de Paiva ${ }^{1}$; Anaclara Ferreira Veiga Tiplle² ${ }^{2}$ Eliane de Paiva e Silva ${ }^{3}$; \\ Divina das Dores de Paula Cardoso ${ }^{3}$
}

${ }^{1}$ Faculdade de Odontologia, Universidade Federal de Goiás, Goiânia, GO, Brasil; ${ }^{2}$ Faculdade de Enfermagem, Universidade Federal de Goiás, Goiânia, GO, Brasil; ${ }^{3}$ Instituto de Patologia Tropical e Saúde Pública, Universidade Federal de Goiás, Goiânia, GO, Brasil.

Submitted: September 07, 2007; Returned to authors for corrections: November 22, 2007; Approved: February 19, 2008.

\begin{abstract}
The hepatitis B virus (HBV) has been considered the major occupational risk agent for dentists. The Central West region of Brazil is considered an intermediate endemic pattern area, but currently there is no information about the HBV prevalence in dentists of Goiânia, Goiás. This study aimed at the detection of the HBV infection rate and risk factors for dentists of Goiânia and the comparison of the obtained data with the general population and other groups. A randomized sample of 680 professionals participated in this study. All dentists gave written consent for the procedure and filled out a questionnaire about risk factors. The HBV serological markers were analyzed using ELISA test and the presence of anti-HBc was observed in $41(6.0 \%)$ of the dentists. None of them was HBsAg positive. Significant relationships with HBV positivity were observed with gender, the time working as a dentist and the use of incomplete personal protective equipment (PPE). The HBV prevalence found in this group of dentists was lower than the endemic pattern of the general population, other health care workers of the region and the dentists from other regions in Brazil. These results may indicate a positive impact of vaccination considering the high adherence of the dentists to the immunization program (98.4\%). Finally, the use of complete PPE by the majority as well as other standard precautions recommended for health care workers could be responsible for the low HBV seroprevalence.
\end{abstract}

Key-words: HBV; dentists; Hepatitis B

\section{INTRODUCTION}

The hepatitis B virus (HBV) is a worldwide cause of hepatic disease with variations in prevalence from region to region. Hepatitis B prevalence, estimated by detection of a specific antigen (HBsAg) in the adult population, has been observed to vary from 0.1 to $20.0 \%$ in different parts of the world (19).

The HBV is transmitted by percutaneous or mucosal exposure to infected blood or other body fluids and the health care workers (HCW) are considered to be at substantial risk for acquiring or transmitting the virus because of the occupational contact with blood, blood products and other body fluids (14). The occupational risk for HBV acquisition varies according to the work place in the health care setting and the HCW's time of exposure to the agent $(1,6,10)$.

The HBV is considered the major occupational risk agent for dental health care workers. Its prevalence among dentists varies from $2.7 \%$ to $23.5 \%$ for those with clinic activities and from $12.2 \%$ to $44.5 \%$ for those who have surgical specialties $(3,7,12,16,17)$.

Although blood is the main occupational infection source in dentistry, saliva and crevicular fluid should not be ignored. The newly recognized role of the gingival epithelium as a susceptible barrier can explain the presence of blood in saliva, mainly because of the high prevalence, up to $90 \%$, of gingivitis in the population (11).

*Corresponding Author. Mailing address: Faculdade de Odontologia da Universidade Federal de Goiás - Praça Universitária s/n CEP: 74605-220. Phone number: (62) 32096062 Fax: (62) 35211882. E-mail: enilza@terra.com.br 
All HCWs that use or are exposed to needles could be at increased risk of needlestick injury which can lead to infections with bloodborne pathogens. The rate of HBV transmission to susceptible $\mathrm{HCWs}$ ranges from 6 to $30 \%$ after a single needlestick exposure to an HBV-infected patient, and a minimum quantity $(0.0001 \mathrm{ml})$ of contaminated blood is enough for virus transmission (14).

Adoption of standard precautions, particularly immunization, constitutes an efficient strategy to prevent hepatitis B in HCWs. Since the 1980s, occupational infections have declined in some parts of the world because of the vaccine use and adherence to standard precautions (14).

The vaccine against hepatitis $B$ produced by recombinant DNA technology was first licensed in 1986, and it is safe and efficient in more than $90 \%$ of healthy subjects. In Brazil, HBV vaccine was introduced for risk groups in 1992 through the National Immunization Program and became available to all HCWs since 1994 (6).

The Central West region of Brazil has been considered as $\mathrm{HBV}$ intermediate endemicity pattern area and the expected HBV infection rate in the general population is between $2.0 \%$ and $7.0 \%$. Several studies related to HBV have been carried out in Goiânia, Goiás in the general population and in risk groups, and it was observed that the rate of seroprevalence varies from $6.1 \%$ - urban female population (8) to $63.4 \%$ - dialysis center patients (4). In addition, studies from different groups of HCWs, found a seroprevalence of $23.4 \%$ in hospital workers (1), $23.1 \%$ in workers at hemodialysis centers (15) and $24.1 \%$ in laboratory workers(20). However, there are no studies regarding the hepatitis B infection in dentists.

This study shows the HBV infection rate and risk factors for dentists from Goiânia-GO, a city located in the Central West region of Brazil, in comparison with data from the general population and from other groups.

\section{MATERIALAND METHODS}

This is a cross-sectional study to evaluate HBV infection rate and risk factors in dentists from Goiânia-GO, Brazil.

\section{Population: enrollment of participants and sampling}

Of the total of 3030 dentists of Goiânia registered at the Regional Council of Dentistry of Goiás in 2005, 680 participated of this study. Considering an expected HBV infection rate for HCWs in region of $23.5 \%(1,20)$ it was estimated that 673 dentists would be representative, with $3 \%$ margin of error, $95 \%$ of confidence level and a $10 \%$ safety margin.

The only requirement for dentists to participate in the study was to be registered at Regional Council of Dentistry of Goiás with professional practice in Goiânia.

The enrollment of dentists occurred at meetings and dental health settings. An invitation for participation in the research was sent to all dentists of Goiânia by an insertion in the journal of the XIII International Congress of Dentistry, in Goiás. During this meeting, 250 dentists were enrolled in the study. The remaining 430 dentists were contacted in other occasions. In this way, data collection and blood sampling were performed in seven scientific events, six public health settings and 30 private dental clinics located in ten different city districts, throughout 2005.

This study was approved by the Ethical Committee of human and animal research of the Clinical Hospital of the Federal University of Goiás (nr. 110/2003).

\section{Measures}

A questionnaire requesting demographic information about potential risk factors for HBV infection was built and validated. This was a self-administered questionnaire, filled out by each participant in the presence of one researcher, at the same time of blood collection.

The questionnaire contained questions about non occupational and occupational risk factors: 1) ever used intravenous illicit drugs, 2) ever had tattooing, piercing, blood transfusion or acupuncture, 3) had sex with more than one partner over a six-month period, 4) PPE use, 5) ever had a needlestick exposure, 6) have surgery specialty, 7) data of previous HBV vaccination and 8) years of working as dentist.

\section{Detection of HBV serological markers}

All the blood samples were analyzed for HBsAg, anti-HBs and total anti-HBc by a immunoenzymatic method using a commercial kit (Bioelisa - Biokit, Spain). The samples were considered positive or negative when optic density was either $10 \%$ above or below the cut off value as recommended by the manufacturer. Samples with doubtful results were retested using a different commercial kit. Two dentists needed a second blood sample collection in order to confirm the initial results.

The sample was considered positive for HBV when total anti-HBc and/or HBsAg were present.

\section{Statistical analysis}

Data were analyzed using the Epi Info 3.22 (CDC, Atlanta USA, 2004) statistical software package. A Chi-square test with $95 \%$ confidence intervals was utilized when necessary. Odds ratio (OR) for each variable and multivariate analysis were utilized to evaluate $\mathrm{HBV}$ risk factors.

\section{RESULTS}

From 3,030 dentists with professional practice in Goiânia in 2005,680 participated of the study. From them, 381 (56\%) were female and 299 (44\%) male professionals. The mean age was 37.2 years $(\mathrm{SD} \pm 10.8)$. These dentists work in different places: $26(3.8 \%)$ as dental school professors, $64(9.4 \%)$ in the public 
health care setting only, $171(25.1 \%)$ in public and private settings and the other $419(61.6 \%)$ in a private setting. Vaccination was admitted by $669(98.4 \%)$ dentists but from them, $77(11.3 \%)$ did not complete the three-dose vaccination schedule.

Gloves and masks were the most PPE used, $99.3 \%$ and $99.1 \%$, respectively. Protective eyewear was the less adopted PPE (89.7\%) (Table 1).

\section{Detection of HBV serological markers}

Table 2 shows that from 680 dentists, $41(6.0 \%)$ were positive for total anti-HBc, and none of them presented HBsAg in the serum. Only one dentist presented detectable total anti-HBc, with the other 40 being also positive to anti-HBsAg. The analysis of the second blood samples collected confirmed the first result.

\section{Occupational and non occupational risk factors}

Positivity for $\mathrm{HBV}$ related to non occupational risk factors is shown in Table 3. Only gender was significantly related to HBV positivity. Male dentists were twice more positive than female dentists ( $\mathrm{OR}=2.08 ; \mathrm{CI}=1.09-3.97)$.

In relation to occupational risk factors it was observed that the adoption of some PPEs rather than all of them was significantly $(p<0.05)$ associated with HBV seroprevalence. The

Table 1. Frequency of use of personal protective equipment (PPE) and HBV vaccination among 680 dentists in Goiânia, Brazil.

\begin{tabular}{lcc}
\hline \multicolumn{1}{c}{ PPE* } & Yes (\%) & No (\%) \\
\hline Gloves & $675(99.3)$ & $5(0.7)$ \\
Masks & $674(99.1)$ & $6(0.9)$ \\
Protective clothing & $657(96.6)$ & $23(3.4)$ \\
Protective hair & $632(92.9)$ & $48(7.1)$ \\
Protective eyewear & $610(89.7)$ & $70(10.3)$ \\
HBV vaccine** & $669(98.4)$ & $11(1.6)$ \\
\hline
\end{tabular}

*Personal Protective Equipament

** HBV vaccine is considered a personal protective measure

Table 2. Seroprevalence of HBV infection in 680 dentists from Goiânia-GO, 2005.

\begin{tabular}{lcc}
\hline \multicolumn{1}{c}{ Serological markers } & Positive/Total & $\%$ \\
\hline HBsAg* & $0 / 680$ & 0.0 \\
Total Anti-HBcAg/Anti-HBsAg** & $40 / 680$ & 5.9 \\
Total anti-HBcAg*** & $1 / 680$ & 0.1 \\
\hline Total & $41 / 680$ & 6.0 \\
\hline
\end{tabular}

* HBsAg - hepatitis B surface antigen; ** Anti-HBsAg - antibody to hepatitis B surface antigen; *** Total anti-HBc - antibody to hepatitis $\mathrm{B}$ core antigen total
Table 3. Seroprevalence of HBV infection in 680 dentists from Goiânia-GO and the associated non-occupational risk factors.

\begin{tabular}{lcccccc}
\hline $\begin{array}{l}\text { Risk } \\
\text { Factors }\end{array}$ & $\begin{array}{c}\text { Positive/ } \\
\text { Total }\end{array}$ & $\begin{array}{c}\text { Negative/ } \\
\text { Total }\end{array}$ & $\begin{array}{c}\mathrm{P}^{*} \\
\text { value }\end{array}$ & $\begin{array}{c}\text { OR } \\
\text { CI95\% }\end{array}$ \\
\hline $\begin{array}{l}\text { Drug use } \\
\quad \text { Yes }\end{array}$ & $41 / 675$ & 6.1 & $5 / 5$ & 100.0 & & \\
$\quad$ No & $41 / 675$ & 6.1 & $634 / 675$ & 93.9 & & \\
$\begin{array}{c}\text { Acupuncture } \\
\quad \text { Yes }\end{array}$ & $4 / 102$ & 3.9 & $98 / 102$ & 96.1 & & $0.21-1.71$ \\
$\quad$ No & $37 / 578$ & 6.4 & $541 / 578$ & 93.6 & & \\
$\begin{array}{c}\text { Sexual } \\
\text { Yes }\end{array}$ & $2 / 75$ & 2.7 & $73 / 75$ & 97.3 & & $0.09-1.68$ \\
$\quad$ No & $39 / 605$ & 6.4 & $566 / 605$ & 93.6 & & \\
Tattooing & & & & & 0.33 & 0.39 \\
$\quad$ Yes & $1 / 40$ & 2.5 & $39 / 40$ & 97.5 & & 0.39 \\
$\quad$ No & $40 / 653$ & 6.1 & $613 / 653$ & 93.9 & & \\
Gender & & & & & 0.02 & 2.08 \\
$\quad$ Female & $365 / 381$ & 95.8 & $16 / 381$ & 4.2 & & $1.09-3.97$ \\
$\quad$ Male & $274 / 299$ & 91.6 & $25 / 299$ & 8.4 & & \\
\hline Total & $41 / 680$ & 6.0 & $639 / 680$ & 93.9 & & \\
\hline
\end{tabular}

* $\mathrm{p}$ value from $\chi^{2}$ test; **OR - Odds Ratio and CI - Confidence interval $* * *$ Drug use - used intravenous illicit drug during a six-month period; $* * * *$ Acupuncture, tattooing, piercing or blood transfusion ever had; ***** Sexual - Sex with more than one partner over a sixmonth period.

same occurred with variable "years of work" $(\mathrm{p}<0.001)$. Among dentists with up to 20 years of professional practice, around $3.0 \%$ were positive, and in those with more than 20 years, $17.6 \%$ of seroprevalence was found (Table 4). The logistic regression analysis for HBV infection in relation to risk factors showed that 20 years or more of working as a dentist was significantly $(\mathrm{OR}=10.24, \mathrm{CI}=4.82-21.78)$ associated with infection rate (Table 5).

\section{DISCUSSION}

This is the first HBV seroprevalence evaluation in dentists from Goiânia. Many groups of workers exposed to blood or body fluids recognize HBV infection as a risk. The dentists have been considered at an increased risk because of their routine work with sharp instruments in exposure-prone procedures (6). The rate of $6.0 \%$ for $\mathrm{HBV}$, in relation to total anti- $\mathrm{HBc}$ and the negativity for $\mathrm{HBsAg}$ observed in this study disagree with the intermediate endemicity pattern admitted for the Central West region of Brazil for the general population -2 to $7 \%$ of positivity for HBsAg. In this way, the data also disagree with the assertive "the dentists are considered three to five times more at risk for hepatitis B than the general population" (5). 
Table 4. Seroprevalence of HBV infection in 680 dentists from Goiânia-GO, 2005, and the associated occupational risk factors.

\begin{tabular}{lcccccc}
\hline $\begin{array}{l}\text { Risk } \\
\text { Factors }\end{array}$ & $\begin{array}{c}\text { Positive/ } \\
\text { Total }\end{array}$ & $\begin{array}{c}\% \\
\text { Total }\end{array}$ & $\begin{array}{c}\text { Negative/ } \\
\text { To value }\end{array}$ & $\begin{array}{c}\text { OR* } \\
\text { (CI95\%) }\end{array}$ \\
\hline $\begin{array}{l}\text { Exposure** } \\
\quad\end{array}$ & & & & & 0.36 & 1.38 \\
$\quad$ Yes & $29 / 436$ & 6.7 & $407 / 436$ & 93.3 & & $0.69-2.75$ \\
$\quad$ No & $12 / 244$ & 4.9 & $232 / 244$ & 95.1 & & \\
Specialty*** & & & & & 0.25 & 0.66 \\
$\quad$ Yes & $12 / 150$ & 8.0 & $138 / 150$ & 92.0 & & $0.33-1.34$ \\
$\quad$ No & $29 / 530$ & 5.5 & $501 / 530$ & 94.5 & & \\
Vaccine**** & & & & & 0.88 & 1.07 \\
$\quad$ No & $5 / 88$ & 5.7 & $83 / 88$ & 94.3 & & $0.41-2.82$ \\
$\quad$ Complete & $36 / 592$ & 6.1 & $556 / 592$ & 93.9 & & \\
Years of work & & & & & $<0.001$ & NR***** \\
$\quad 0-5$ & $3 / 188$ & 1.6 & $185 / 188$ & 98.4 & & \\
$\quad>05-10$ & $2 / 138$ & 1.4 & $136 / 138$ & 98.6 & & \\
$\quad>10-20$ & $6 / 184$ & 3.3 & $177 / 184$ & 96.7 & & \\
$\quad>20$ & $30 / 170$ & 17.6 & $140 / 170$ & 82.4 & & \\
PPE***** & & & & & 0.02 & 0.42 \\
$\quad$ all & $30 / 583$ & 5.1 & $553 / 583$ & 94.9 & & $0.20-0.88$ \\
$\quad$ some & $11 / 97$ & 11.3 & $86 / 97$ & 88.7 & & \\
\hline
\end{tabular}

* p value from $\chi^{2}$ test; ** Needlestick exposure - ever had in dental practice; *** Oral Surgery Specialties - periodontics, endodontics and implantology were included in it; ****NO or Inc-No vaccination or incomplete schedule (less then three doses); ${ }^{* * * * *} \mathrm{NR}$ - not realized (more than two exposure variables); $* * * * * *$ PPE - Personal protective equipment (masks, gloves, protective eyewear, protective clothing and hair protection)

Table 5. Occupational and non occupational risk factors to HBV infection in logistic regression analysis in 680 dentists from Goiânia, Brazil, 2005.

\begin{tabular}{lcc}
\hline \multicolumn{1}{c}{ Risk Factor } & Odds Ratio & \multicolumn{1}{c}{$95 \% \mathrm{CI}^{*}$} \\
\hline PPE** $^{* *}$ & 0.97 & $0.43-2.19$ \\
Oral Surgery Specialties*** & 0.50 & $0.23-1.09$ \\
Gender**** & 1.66 & $0.82-3.34$ \\
Vaccination***** & 1.05 & $0.38-2.92$ \\
Years of work & 10.24 & $4.82-21.78$ \\
\hline
\end{tabular}

*CI - Confidence interval; **PPE - Personal protective equipments (masks, gloves, protective eyewear, protective clothing and protective hair); ***Oral Surgery Specialties - periodontics, endodontics and implantology were included in it; ****Gender-male; *****Vaccination - No vaccination or incomplete schedule (less then three doses) versus complete three-dose schedule.

This assertive seems to be corroborated by studies conducted in HCW from Goiânia that show higher rates of positivity for $\mathrm{HBV}$ as $23.4 \%$ for HCWs from three hospitals (1), $24.3 \%$ in hemodialysis staff (15) and $24.1 \%$ in workers from laboratory (20). The first study was carried out during the pre-vaccination era, but the others were performed after the beginning of the hepatitis $\mathrm{B}$ vaccination program for HCWs in Brazil in 1994. Therefore, it seems that the rate of $\mathrm{HBV}$ infection in HCWs has not changed much through the years in this region, remaining around $24.0 \%$.

The positivity rate for HBV infection observed in this study is lower than in others performed in Brazil. A rate of $23.3 \%$ was found among a group of dentists in the Southeast region - Minas Gerais- in the mid-1990s (16). Studies in other states have found lower percentages, such as $10.4 \%$ in Rio de Janeiro (7), 9.5\% and $8.9 \%$ in São Paulo $(17,18)$.

The highest HBV infection rate observed in Brazilian dentists was $31.2 \%$, in 250 professionals in the South (2). This study was conducted between 1989 and 1990, i.e., before the $\mathrm{HBV}$ vaccination era.

The only study performed among dentists in the Central West region of Brazil was conducted in Campo Grande- MS and showed $10.8 \%$ positivity for $\mathrm{HBV}$ in 474 dentists (3).

Routine hepatitis B vaccination of $\mathrm{HCW}$ and use of standard precautions to prevent exposure to bloodborne pathogens have had a positive impact in HBV epidemiology among such populations, worldwide (9). Although it is not possible to evaluate the impact of the vaccination in HBV infection prevalence in $\mathrm{HCW}$ s since official data about vaccine response and/or coverage in this specific population are unavailable, we consider that the high adherence of the dentists $(98.4 \%)$ to HBV could be a personal protective measure with positive impact for this population.

The sample used in this study was representative of the population, considering the distribution among different ages and years of working. Therefore, a low possibility of bias in younger age groups or among those with fewer years of dental practice was expected. Nevertheless, a limitation of the study could be the lack of data from individuals that did not participate in the study.

In this study it was observed that HBV infection rate predominated among male dentists. This result is in agreement with a previous study performed in the Southeast region of Brazil among HCWs (10).

The occupational risk for HBV infection and the standard precautions must be analyzed in relation to different rates of positivity for HBV among dentists. Age is the variable usually associated with HBV positivity as well as the length of viral exposure. A study with dental students, before and after contact with patients, found $\mathrm{HBV}$ infection rates of $6.8 \%$ and $7.1 \%$, respectively in comparison, a higher rate (23.3\%) was observed for dentists. Another aspect is that younger professionals adhere more closely to the standard guidelines (16).

In addition, HCW studies usually show that the number of years in the profession can be a risk factor $(1,10,13,15,20)$, 
including dentists $(3,7,16,17)$ as observed in the present study. For dentists with up to 20 years of profession the HBV prevalence was around 3.0\% in comparison to dentists with more than 20 years of work $-17.6 \%$. The logistic regression analysis showed that the years of work was the main risk factor for acquiring HBV infection.

Sice the 1990s, the dental schools in Goiania have put an effort on the new infection control curriculum and in continued professional training (21). The majority of dentists of this study claimed to have used all the PPE and the other standard precautions, including vaccination. Nevertheless, there was a significant association of HBV infection with incomplete PPE use. These results are in accordance with other studies $(10,18)$.

The HBV prevalence in dentists found in this study was lower than the prevalence found in other groups studied in the same region. It was also the lowest rate among studies with Brazilian dentists. The comparison of HBV seroprevalence and occupational risk factors showed a high significance for number of years working as well as the incomplete PPE use by dentists.

The data of a high index of vaccinated dentists and a low HBV infection rate reinforce the relevance of the National Immunization Program and more efforts must be employed to enhance the HCWs adherence to the program. It is possible that a higher adherence to the vaccination by the dentists could have been achieved by the Regional Council of Dentistry of Goiás that promoted a second opportunity for vaccination, in 2002. This action probably had a positive impact in the infection rate among the dentists from Goiânia.

\section{ACKNOWLEDGEMENTS}

The authors would like to express their gratitude to Dr. Joaquim Tomé de Souza for statistical support of this manuscript.

\section{RESUMO}

\section{Marcadores sorológicos e fatores de risco relacionados ao vírus da hepatite $B$ em dentistas da região Centro Oeste do Brasil}

O vírus da hepatite $\mathrm{B}$ (VHB) tem sido considerado o agente de maior risco ocupacional para o cirurgião-dentista (CD). A região Centro Oeste do Brasil é considerada de padrão endêmico intermediário para a infecção pelo vírus e não há informações sobre a prevalência do VHB em CD da cidade de Goiânia, Goiás. Este estudo objetivou determinar a soroprevalência da infecção pelo VHB e fatores de risco relacionados em CD de Goiânia comparando com dados da população geral e outros grupos populacionais. Uma amostra randomizada de 680 profissionais participou deste estudo. Após consentimento escrito, todos os $\mathrm{CD}$ responderam um questionário com informações sobre fatores de risco. Os marcadores sorológicos da infecção para o VHB foram analisados por meio do teste ELISA tendo sido observado o marcador de infecção viral, anti-HBc, em 41 (6.0\%) dentistas, nenhum deles positivo para o HBsAg. Associações significantes com a positividade ao VHB foram observadas em relação a gênero, ao tempo de trabalho e ao uso incompleto de equipamentos de proteção individual (EPI). A soroprevalência ao VHB observada em CD foi inferior ao da população geral, para outros grupos de profissionais de saúde na mesma região e para CD de outras regiões do Brasil. Os resultados deste estudo sugerem impacto positivo da vacinação, considerando a alta adesão pelos CD ao programa de imunização $(98,4 \%)$. Finalmente, a adoção de todos os EPI pela maioria dos CD assim como às outras medidas de precauções padrão recomendadas para profissionais de saúde pode justificar a menor soroprevalência observada.

Palavras-chave: HBV; Cirurgiões-dentistas; Hepatite B

\section{REFERENCES}

1. Azevedo, M.S.P.; Cardoso, D.D.P.; Martins, R.M.B.; Daher, R.R.; Camarota, S.C.T.; Barbosa, A.J. (1994). Rastreamento sorológico para heptite B em profissionais de saúde na cidade de Goiânia- Goiás. Rev. Bras. Med. Trop., 27 (3), 157-162.

2. Baldy, J.L.; Elisbao, M.C.; Anzai, E.T.; Pontello, R.; Reiche, E.M.; Zaha-Inouye, M.M.; Matsuo, T.; Tonani, P.C.; Ferelle, A.; Henriques, J.N.; Neves, J. (2003). Intradermal vaccination of adults with three low doses (2 micrograms) of recombinant hepatitis B vaccine. I. Seroconversion rate and adverse effects. Mem. Inst. Oswaldo Cruz, 98 (8), 1101-7.

3. Batista, S.M.; Andreasi, M.S.; Borges, A.M.; Lindenberg, A.S.; Silva, A.L.; Fernandes, T.D.; Pereira, E.F.; Basmage, E.A.; Cardoso, D.D. (2006). Seropositivity for hepatitis B virus, vaccination coverage, and vaccine response in dentists from Campo Grande, Mato Grosso do Sul, Brazil. Mem. Inst. Oswaldo Cruz, 101 (3), 263-7.

4. Borges, A.M.T.; Cardoso, D.D.P.; Martins, R.M.B. (1997). Hepatite B em pacientes de centros de diálise de Goiânia-GO. Rev. Patol. Trop., 26 (1), 09-16.

5. Brasil-MS (1994). Hepatites, Aids e Herpes na prática odontológica. Ministério da Saúde - DST/AIDS. 56p

6. Brasil-MS (2006). Exposição a Materiais Biológicos. Editora MS.

7. Camilo, R.S. (1998). Prevalência das hepatites B e C nos cirurgiõesdentistas da Faculdade de odontologia da UFRJ. Rio de Janeiro-RJ, Brasil, 96 p. (M.Sc. Dissertation. Faculdade de odontologia, UFRJ)

8. Cardoso, D.D.P.; Azevedo, M.S.P.; Martins, R.M.B.; Barbosa, A.J.; Camarota, S.C.T. (1990). Soroprevalência para infecção pelo Vírus da hepatite B pelos marcadores AgHBs e anti-HBs em população feminina de área urbana de Goiânia-GO. Rev. Pat. Trop., 19 (2), 135-141.

9. Centers for Disease Control and Prevention - CDC (2006). Hepatitis $B$ vaccination coverage among adults-United States, 2004. MMWR. 509-11.

10. Ciorlia, L.A.; Zanetta, D.M. (2005). Hepatitis B in healthcare workers: prevalence, vaccination and relation to occupational factors. Braz. J. Infect. Dis., 9 (5), 384-9.

11. Dale, B.A. (2002). Periodontal epithelium: a newly recognized role in health and disease. Periodontol. 2000, 30, 70-8.

12. Feres Filho, E.J. (1991). Inquérito epidemiológico da hepatite B nos cirurgiões-dentistas da Faculdade de odontologia da UFRJ. Rio de Janeiro- RJ, Brasil, 97p. (M.Sc. Dissertation. Faculdade de odontologia. UFRJ). 
13. Fernandes, J.V.; Braz, R.F.; Neto, F.V.; Silva, M.A.; Costa, N.F.; Ferreira, A.M. (1999). Prevalence of serologic markers of hepatitis B virus in hospital personnel. Rev. Saúde Pública, 33(2), 122-8.

14. Kohn, W.G.; Collins, A.S.; Cleveland, J.L.; Harte, J.A.; Eklund, K.J.; Malvitz, D.M. (2003). Guidelines for infection control in dental health-care settings-2003. MMWR RR-52 (RR-17), 1-61.

15. Lopes, C.L.R.; Martins, R.M.B.; Teles, S.A.; Silva, S.A.; Maggi, P.S.; Yoshida, C.F.T. (2001). Perfil soroepidemiológico da infecção pelo vírus da hepatite $\mathrm{B}$ em profissionais das unidades de hemodiálise de Goiânia-Goiás, Brasil Central. Rev. Soc. Bras. Med. Trop., 34 (6), 543-48.

16. Ottoni, C.M.; Penna, F.J.; Oliveira, C.G.; Souza, C.J. (1995). Prevalence of serologic markers of hepatitis B in dentistry students and dentists in Belo Horizonte, Brazil. Bol. Oficina Sanit. Panam., 118 (2), 108-14.

17. Rodrigues, V.C. (2002). Hepatite B no município de Ribeirão PretoSP: um estudo envolvendo cirurgiões-dentistas e auxiliares odontológicos. Ribeirão Preto-SP, Brasil, 84 p. (Thesis. Faculdade de Odontologia. USP, Ribeirão Preto-SP).

18. Rodrigues, W.T.B. (2003). Avaliação do perfil sorológico para hepatite B e C e exposição ocupacional entre cirurgiões-dentistas de Sertãozinho-SP. Ribeirão Preto-SP, Brasil, 150 p. (M.Sc. Dissertation. Faculdade de Medicina. USP, Ribeirão Preto-SP).

19. Shepard, C.W.; Simard, E.P.; Finelli, L.; Fiore, A.E.; Bell, B.P. (2006). Hepatitis B virus infection: epidemiology and vaccination. Epidemiol. Rev., 28, 112-25.

20. Silva, P.A.; Fiaccadori, F.S.; Borges, A.M.; Silva, S.A.; Daher, R.R.; Martins, R.M.; Cardoso, D.D. (2005). Seroprevalence of hepatitis B virus infection and seroconvertion to anti-HBsAg in laboratory staff in Goiânia, Goiás. Ver. Soc. Bras. Med. Trop., 38 (2), 153-6.

21. Tipple, A.F.V.; Souza, A.C.S.; Sousa, C.P.; Paiva, E.M.M.; Pereira, M.S. (2003). Equipamentos de Proteção Individual: uso e manuseio por alunos em uma instituição de ensino odontológico. Rev. $A B O$ Nacional, 11 (3), 153-161. 